\title{
Degradation of FBL Dye Wastewater by Magnetic Photocatalysts from Scraps
}

\author{
Robert Liu, ${ }^{1,2}$ Chia Feng Wu, ${ }^{1}$ and Ming Der Ger ${ }^{3}$ \\ ${ }^{1}$ Department of Chemical and Materials Engineering, Minghsin University of Science and Technology, Hsinchu 30401, Taiwan \\ ${ }^{2}$ Graduate School of Defense Science, Chung Cheng Institute of Technology, National Defense University, Taoyuan 335, Taiwan \\ ${ }^{3}$ Department of Chemical and Materials Engineering, Chung Cheng Institute of Technology, National Defense University, \\ Taoyuan 335, Taiwan
}

Correspondence should be addressed to Robert Liu; robertl@must.edu.tw

Received 29 September 2014; Accepted 6 January 2015

Academic Editor: Chunyi Zhi

Copyright (C) 2015 Robert Liu et al. This is an open access article distributed under the Creative Commons Attribution License, which permits unrestricted use, distribution, and reproduction in any medium, provided the original work is properly cited.

Magnetic photocatalyst solves the separation problem between wastewater and $\mathrm{TiO}_{2}$ photocatalysts by the application of magnetic field. This research investigates the treatment of simulated $\mathrm{FBL}$ dye wastewater using $\mathrm{Mn}-\mathrm{Zn}$ ferrite $/ \mathrm{TiO}_{2}$ magnetic photocatalyst. The magnetic $\mathrm{Mn}-\mathrm{Zn}$ ferrite powder was first produced by a chemical coprecipitation method from spent dry batteries and spent pickling acid solutions. These two scraps comprise the only constituents of Mn-Zn ferrite. The as-synthesized Mn-Zn ferrite was then suspended in a solution containing $\mathrm{Ti}\left(\mathrm{SO}_{4}\right)_{2}$ and urea. Subsequently a magnetic photocatalyst was obtained from the solution by chemical coprecipitation. The prepared $\mathrm{Mn}-\mathrm{Zn}$ ferrite powder and magnetic photocatalyst $\left.(\mathrm{Mn}-\mathrm{Zn} \text { ferrite/TiO})_{2}\right)$ were characterized using XRD, EDX, SEM, SQUID, BET, and so forth. The photocatalytic activity of the synthesized magnetic photocatalysts was tested using degradation of FBL dye wastewater. The adsorption and degradation studies by the TOC and ADMI measurement were carried out, respectively. The adsorption isotherm and Langmuir-Hinshelwood kinetic model for the prepared magnetic $\mathrm{TiO}_{2}$ were proved to be applicable for the treatment. This research transforms waste into a valuable magnetic photocatalyst.

\section{Introduction}

Wastewaters from textile and dyeing industries are highly colored by various nonbiodegradable dyes which cause serious environmental problems [1]. Advanced oxidation processes such as $\mathrm{UV} / \mathrm{H}_{2} \mathrm{O}_{2}$ [2], ozonation [1,3-5], Fenton processes [5-8], ozone/Fenton [9], $\mathrm{TiO}_{2}$, and modified $\mathrm{TiO}_{2}[10-17]$ are promising alternatives for the mineralization of textile dyes or other pollutants. Among them, the semiconductor $\mathrm{TiO}_{2}$ 's simultaneous photocatalytic oxidation and reduction process show the significant potential due to its being photoreactive, nontoxic, chemically and biologically inert, photostable, and lower in cost. Among different advanced oxidation processes (AOPs), a relatively new AOP, sonolysis or hybrid AOPs with combination of sonolysis, has drawn increasing attention as it generates the $\bullet \mathrm{OH}$-free radical through the phenomenon of transient cavitation by ultrasound irradiation [18-20].
Cavitation is essentially nucleation, growth, and transient implosive collapse of gas bubbles driven by ultrasound wave.

Manganese zinc ferrites are important ferrimagnetic materials because of their high magnetic permeability and low magnetic hysteresis loss [21]. Ferrites are commonly produced using a ceramic process that involves a high temperature calcination of oxide and/or carbonates. Their main disadvantages are their large and nonuniform size distribution, poor reproducibility, contamination, and a need for the application of high temperature for production [22]. Therefore, several wet chemical methods have been used to prepare fine $\mathrm{Mn}-\mathrm{Zn}$ ferrite powders, such as the citrate precursor method [23, 24], the autocombustion method [25], the hydrothermal method [26], the sol-gel method [27], and the coprecipitation method [28]. A rather new technique for the ferrite synthesis is the sonochemical method in 
which ferrite nanoparticles are prepared using ultrasound irradiation or sonication of the reaction mixture $[29,30]$.

Despite existing technologies, nanosized $\mathrm{TiO}_{2}$ particles remain difficult to separate from treated wastewater. Fixedfilm- $\mathrm{TiO}_{2}$ systems are undermined by their own immobility, while magnetic $\mathrm{TiO}_{2}$ systems offer to overcome this limitation. For example, Ma et al. [31] synthesized titania-coated $\mathrm{Mn}-\mathrm{Zn}$ ferrite by hydrolysis of titanium chloride $\left(\mathrm{TiCl}_{4}\right)$ in the presence of $\mathrm{Mn}-\mathrm{Zn}$ ferrite nanoparticles, which were prepared by a stearic acid sol-gel method. The magnetization of the $\mathrm{TiO}_{2}$-coated $\mathrm{Mn}-\mathrm{Zn}$ ferrite particles was reduced, unlike the uncoated ferrite nanoparticles, and high coercivity was obtained $\left(H_{c}>100 \mathrm{Oe}\right)$ for both prepared uncoated and coated ferrite particles. It was also found that the synthesized photocatalysts were not superparamagnetic. Chen and Zhao [32] reported a magnetically separable photocatalyst of $\mathrm{TiO}_{2} / \mathrm{SiO}_{2} / \gamma-\mathrm{Fe}_{2} \mathrm{O}_{3}$ which was prepared using the solid phase synthesis method. The addition of a $\mathrm{SiO}_{2}$ membrane between the $\gamma-\mathrm{Fe}_{2} \mathrm{O}_{3}$ core and the $\mathrm{TiO}_{2}$ shell weakened the adverse effects of $\gamma-\mathrm{Fe}_{2} \mathrm{O}_{3}$ on the photocatalysis of $\mathrm{TiO}_{2}$. The photocatalyst described in Chen and Zhao's article showed good photocatalytic activity and it was able to separate from the solution through the use of a magnetic field. Gao et al. [33] synthesized a magnetically separated photocatalyst of $\mathrm{TiO}_{2} / \gamma-\mathrm{Fe}_{2} \mathrm{O}_{3}$ by a sol-gel method. The sample sintered at $500^{\circ} \mathrm{C}$ showed the highest activity for the degradation of an acridine dye aqueous solution, with the optimal supporting amount of $\mathrm{TiO}_{2}$ approximating 50\%. Fu et al. [34] successfully prepared $\mathrm{TiO}_{2} / \mathrm{NiCuZn}$ ferrite composite powder as a magnetic photocatalyst. The core NiCuZn ferrite powder was synthesized using waste material from steel and electroplating industries. The shell of the $\mathrm{TiO}_{2}$ nanocrystal was prepared by a sol-gel hydrolysis method of titanium isopropoxide with $\mathrm{NiCuZn}$ ferrite powder, followed by heat treatment. In their study [34], the optimum dosage of the magnetic photocatalyst was $2.67 \mathrm{~g} / \mathrm{L}$ for treating a methylene blue solution.

In this research, a simple magnetic photocatalyst preparation method was undertaken. First, $\mathrm{Mn}-\mathrm{Zn}$ magnetic ferrite powder was prepared from spent $\mathrm{Mn}-\mathrm{Zn}$ dry batteries and ferrous sulfate containing spent acid solution from steel plants by using coprecipitation method. Then, the magnetic powder was added to a titanium sulfate solution and the hydroxides of titanium were precipitated at desired $\mathrm{pH}$ using urea solution. After filtration, drying, and grinding, the precipitates were sintered at $500^{\circ} \mathrm{C}$ under $\mathrm{N}_{2}$ atmosphere to form the magnetic photocatalyst, $\mathrm{Mn}-\mathrm{Zn}$ ferrite/ $\mathrm{TiO}_{2}$. The adsorption and degradation of simulated FBL (Everdirect Supra Turquoise Blue) dye wastewater were carried out by applying self-prepared magnetic photocatalysts under dark as well as under solar irradiation. The adsorption isotherm and L-H kinetic model were also studied.

\section{Materials and Methods}

2.1. Preparation of Magnetic Mn-Zn Ferrite Powder and Magnetic Photocatalyst. The flow diagram for preparing the $\mathrm{Mn}-\mathrm{Zn}$ ferrite powder and ferrite is shown in Figure 1.
The designed composition used was $\mathrm{ZnO}: \mathrm{MnO}: \mathrm{Fe}_{2} \mathrm{O}_{3}=$ $12.5: 35: 52.5$ by molar ratio and $8.56: 20.89: 70.55$ by weight percentages or $\mathrm{Zn}: \mathrm{Mn}: \mathrm{Fe}=0.25: 0.7: 2.1$ by moles and $\mathrm{Zn}: \mathrm{Mn}: \mathrm{Fe}=9.3: 22.4: 68.3$ by weight percentages. The reactions are shown as follows:

$$
\begin{aligned}
& \mathrm{MnO}_{2(\mathrm{~s})}+2 \mathrm{FeSO}_{4(\mathrm{aq})}+\mathrm{ZnO}_{(\mathrm{s})}+3 \mathrm{H}_{2} \mathrm{SO}_{4(\mathrm{aq})} \\
& \longrightarrow \mathrm{MnSO}_{4(\mathrm{aq})}+\mathrm{Fe}_{2}\left(\mathrm{SO}_{4}\right)_{3(\mathrm{aq})}+\mathrm{ZnSO}_{4(\mathrm{aq})}+3 \mathrm{H}_{2} \mathrm{O} \\
& \mathrm{CuSO}_{4(\mathrm{aq})}+\mathrm{Fe}_{(\mathrm{s})} \longrightarrow \mathrm{FeSO}_{4(\mathrm{aq})}+\mathrm{Cu}_{(\mathrm{s})}+3 \mathrm{H}_{2} \mathrm{O} \\
& \mathrm{MnSO}_{4(\mathrm{aq})}+\mathrm{Fe}_{2}\left(\mathrm{SO}_{4}\right)_{3(\mathrm{aq})}+\mathrm{ZnSO}_{4(\mathrm{aq})}+10 \mathrm{NaOH}_{(\mathrm{aq})} \\
& \longrightarrow \mathrm{Mn}(\mathrm{OH})_{2}+2 \mathrm{Fe}(\mathrm{OH})_{3}+\mathrm{Zn}(\mathrm{OH})_{2}+5 \mathrm{Na}_{2} \mathrm{SO}_{4} \\
& x \mathrm{Mn}(\mathrm{OH})_{2}+2 \mathrm{Fe}(\mathrm{OH})_{3}+(1-x) \mathrm{Zn}(\mathrm{OH})_{2} \\
& \longrightarrow \mathrm{Mn}_{x} \mathrm{Zn}_{1-x} \mathrm{Fe}_{2} \mathrm{O}_{4}+4 \mathrm{H}_{2} \mathrm{O}
\end{aligned}
$$

Due to the presence of $\mathrm{Cu}^{+2}$ in the waste acid, iron powder was added to replace copper by reaction (2).

The magnetic photocatalyst was prepared by adding Mn$\mathrm{Zn}$ ferrite magnetic powder $10 \mathrm{~g}$ and urea $\left(\mathrm{N}_{2} \mathrm{H}_{4} \mathrm{CO}\right)$ of $150 \mathrm{~g}$ into $92 \mathrm{~mL}$ of $\mathrm{Ti}\left(\mathrm{SO}_{4}\right)_{2}$ solution. The ratio of $\mathrm{Mn}$ $\mathrm{Zn}$ ferrite powder to $\mathrm{TiO}_{2}$ was $1: 1$ (wt $\%$ ). The flow chart for the preparation of the magnetic photocatalyst of Mn$\mathrm{Zn}$ ferrite/ $/ \mathrm{TiO}_{2}$ is shown in Figure 2. The reactions followed would be

$$
\begin{gathered}
\left(\mathrm{NH}_{2}\right)_{2} \mathrm{CO}+3 \mathrm{H}_{2} \mathrm{O} \longrightarrow 2 \mathrm{NH}_{4} \mathrm{OH}+\mathrm{CO}_{2} \\
\mathrm{Ti}\left(\mathrm{SO}_{4}\right)_{2}+4 \mathrm{NH}_{4} \mathrm{OH} \longrightarrow \mathrm{Ti}(\mathrm{OH})_{4}+2\left(\mathrm{NH}_{4}\right)_{2} \mathrm{SO}_{4} \\
\mathrm{Ti}(\mathrm{OH})_{4} \longrightarrow \mathrm{TiO}_{2}+2 \mathrm{H}_{2} \mathrm{O}
\end{gathered}
$$

2.2. Characterization. The crystalline structure of both magnetic powder and magnetic photocatalyst was examined by XRD (X-ray diffractometer, XRD-6000, Shimadzu, Japan). Their M-H loops were measured by SQUID (superconducting quantum interference device, MPM57, Quantum Design, USA). The chemical compositions of the particles were analyzed by XRF (X-ray fluorescence, XEPOS/XEPO1, Spectro Co., Germany). Their microstructure was observed by SEM (scanning electron microscopy, S-3000N, Hitachi, Japan). The specific area was measured by BET (BrunauerEmmett-Teller, Model-ASAP 2012, Micromeritics, USA).

2.3. Adsorption and Photocatalytic Degradation. The adsorption and photocatalytic reaction were carried out by mixing $1 \mathrm{~L}$ of a FBL dye solution with $5 \mathrm{~g}$ of magnetic $\mathrm{Mn}-\mathrm{Zn}$ ferrite $/ \mathrm{TiO}_{2}$ photocatalysts inside a $2 \mathrm{~L}$ photoreactor beaker, using a teflon agitator under dark and under solar irradiation for $8 \mathrm{hrs}$, respectively. The structure of the FBL dye was shown in [8]. The initial dye concentrations were $\mathrm{COD}=$ 


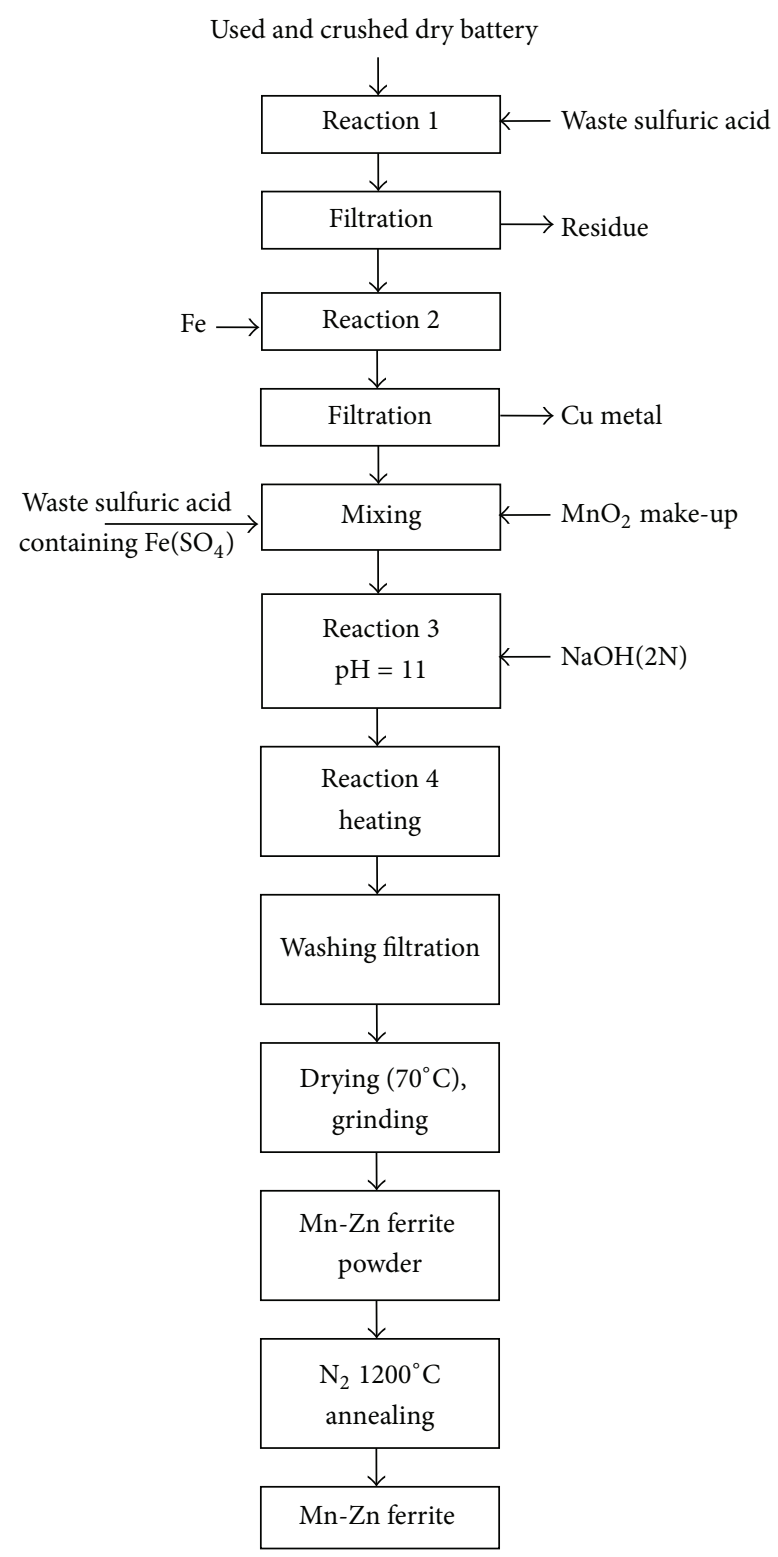

FIgURE 1: Flow chart for preparation of Mn-Zn ferrite by coprecipitation process from zinc-carbon waste dry batteries and waste sulfuric acid.

$100,200,300$, and $400 \mathrm{mg} / \mathrm{L}$ for each experiment. To prepare $\mathrm{COD}=100 \mathrm{mg} / \mathrm{L}, 0.0956 \mathrm{~g}$ of FBL dye was measured to make $1 \mathrm{~L}$ solution. The sampling time was 0 to $480 \mathrm{~min}$ with interval of $40 \mathrm{~min}$, and each sample was taken under mixture condition. After filtration by $0.45 \mu \mathrm{m}$ MFS, the TOC (total organic carbon, Model 1010, O.I. Analytical, USA) and ADMI (American Dye Manufacturers Institute, Model DR/4000V, $\mathrm{HACH}$, USA) were measured for each sample. COD was determined by the potassium dichromate titration method as described in standard methods [35]. Solar intensities were measured by a radiometer (Lutron Co., Taiwan). All solar intensities at $0.5,1,2,3,4,5,6,7$, and 8 hours were measured and averaged and expressed as $I_{\mathrm{av}}\left(\mathrm{mW} / \mathrm{cm}^{2}\right)$.

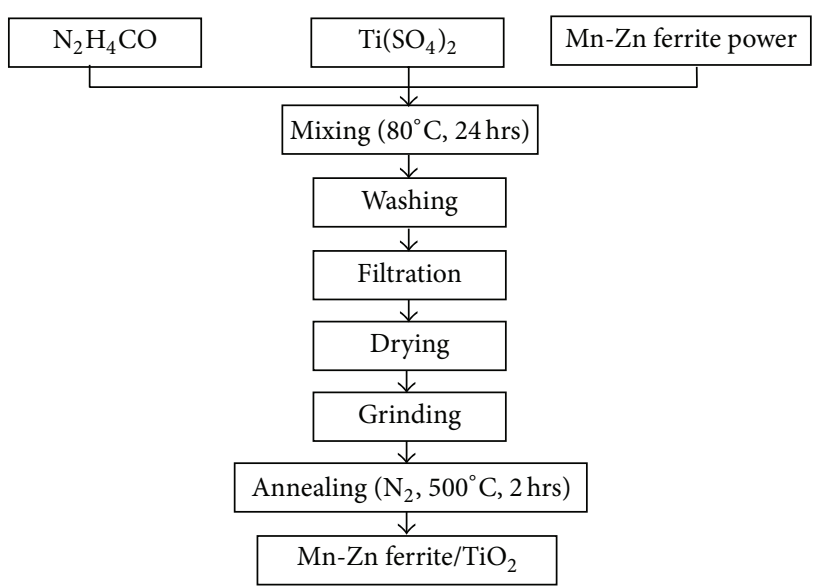

FIGURE 2: Flow chart for the preparation of magnetic photocatalyst of $\mathrm{Mn}-\mathrm{Zn}$ ferrite $/ \mathrm{TiO}_{2}$.

\section{Results and Discussion}

3.1. Characterization of Magnetic Photocatalyst of $\mathrm{Mn}-\mathrm{Zn}$ Ferrite $/ \mathrm{TiO}_{2}$. The XRF analysis of $\mathrm{Mn}-\mathrm{Zn}$ ferrite powder and $\mathrm{Mn}-\mathrm{Zn}$ ferrite/ $/ \mathrm{TiO}_{2}$ is shown in Table 1. It is clear that the experimental values of magnetic powder from waste are close to the quantity used by predetermined value. The designed molar ratio would be $\mathrm{ZnO}: \mathrm{MnO}: \mathrm{Fe}_{2} \mathrm{O}_{3}=12.5: 35: 52.5$. By SEM micrographs, the particle size for the magnetic Mn- $\mathrm{Zn}$ ferrite powder is around $0.24 \mu \mathrm{m}$ and agglomerates into a secondary particle size of approximately $2 \mu \mathrm{m}$ [36]. $\mathrm{TiO}_{2}$ is precipitated on the surface of the secondary particle and its size is approximately $2.5 \mu \mathrm{m}$ (Figure 3 ). The EDX diagram for the $\mathrm{Mn}-\mathrm{Zn}$ ferrite powder and the $\mathrm{Mn}-\mathrm{Zn}$ ferrite/TiO photocatalyst indicates the presence of $\mathrm{Mn}, \mathrm{Zn}, \mathrm{Fe}$, and titanium as shown in Figure 4. The minor $\mathrm{Zn}$ amount existed in the magnetic photocatalysts causing the absence of $\mathrm{Zn}$ in Figure 4(b). The X-ray diffraction patterns of the Mn$\mathrm{Zn}$ ferrite powder, sintered $\mathrm{Mn}-\mathrm{Zn}$ ferrite, and magnetic photocatalysts in Figure 5 revealed that the spinel cubic ferrites and the anatase form of $\mathrm{TiO}_{2}$ exist. All the peaks in the pattern match well with the Joint Committee of Powder Diffraction Standard (JCDDS). The sintered Mn-Zn ferrite at $1200^{\circ} \mathrm{C}\left(\mathrm{N}_{2}\right)$ in Figure $5(\mathrm{~b})$ showed the only existence of the spinel cubic structure which can be used directly in the magnetic industry. A small amount of hematite also existed in the specimens. The surface area of $\mathrm{Mn}-\mathrm{Zn}$ ferrite powder by BET measurement was $8.24 \mathrm{~m}^{2} / \mathrm{g}$ and that of $\mathrm{Mn}-\mathrm{Zn}$ ferrite $/ \mathrm{TiO}_{2}$ is increased to $84.98 \mathrm{~m}^{2} / \mathrm{g}$ which shows more active sites for photoreaction.

3.2. Magnetic Property. The magnetic properties of $\mathrm{Mn}$ $\mathrm{Zn}$ ferrite powder, $\mathrm{Mn}-\mathrm{Zn}$ ferrite, and $\mathrm{Mn}-\mathrm{Zn}$ ferrite/TiO are presented by magnetic hysteresis loops using SQUID as shown in Figure 6. The saturation magnetizations (Ms) of $\mathrm{Mn}-\mathrm{Zn}$ ferrite powder (with and without calcinations) and $\mathrm{Mn}-\mathrm{Zn}$ ferrite $/ \mathrm{TiO}_{2}$ are $63.15,99.37$, and $14.33 \mathrm{emu} / \mathrm{g}$, respectively. The corresponding coercive forces $\left(H_{c}\right)$ are 7.66, 4.60 , and $6.13 \mathrm{Oe}$, respectively. Due to the minimal hysteresis 


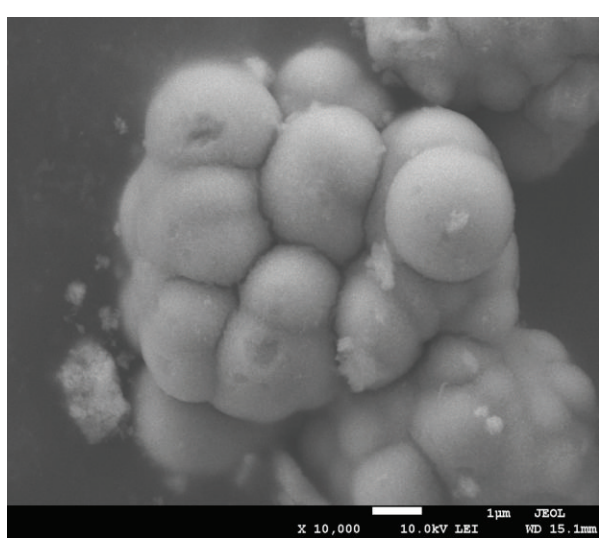

(a)

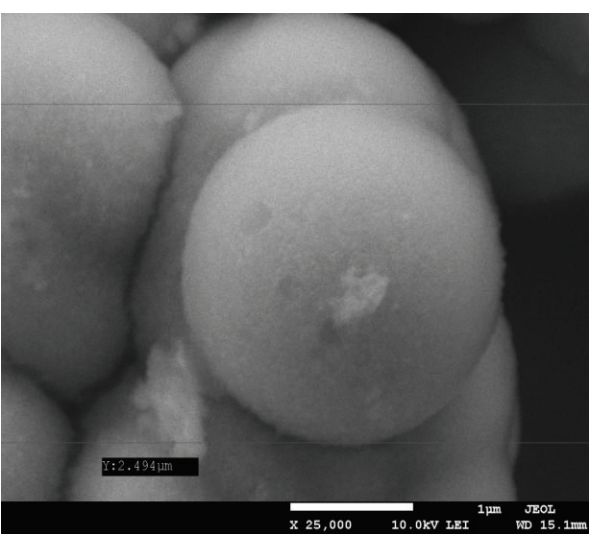

(b)

FIGURE 3: SEM images of self-prepared magnetic photocatalyst of Mn-Zn ferrite/ $\mathrm{TiO}_{2}$ (a) $\times 10000$, (b) $\times 25000$.

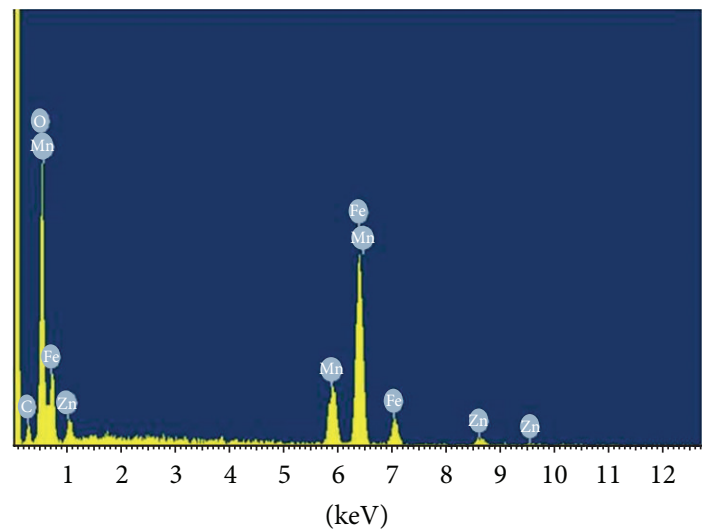

\begin{tabular}{lcc}
\hline Element & (Weight\%) & (Atomic\%) \\
\hline C K & 12.78 & 24.88 \\
O K & 37.18 & 54.32 \\
Mn K & 9.85 & 4.19 \\
Fe K & 36.73 & 15.38 \\
Zn K & 3.46 & 1.24 \\
Totals & 100.00 & \\
\hline
\end{tabular}

Full scale 1647 cts cursor: 0.000

(a)

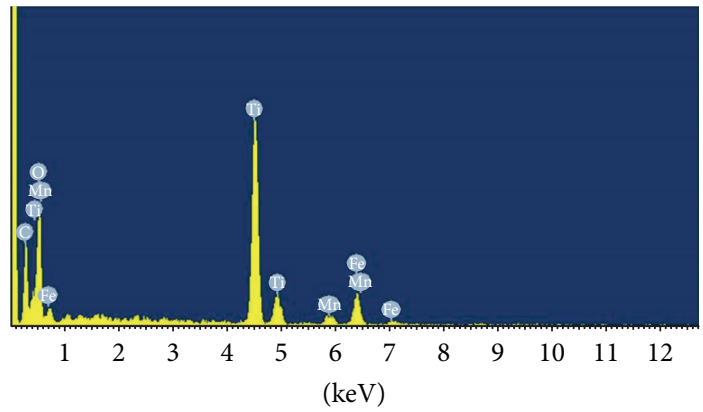

Full scale 1647 cts cursor: 0.000

(b)

FIGURE 4: EDX of Mn-Zn ferrite powder (a) and $\mathrm{Mn}-\mathrm{Zn}$ ferrite/TiO 2 (b).

TABLE 1: XRF analysis of magnetic powder and magnetic photocatalyst.

\begin{tabular}{|c|c|c|c|c|}
\hline Samples & $\mathrm{Fe}_{2} \mathrm{O}_{3}(\mathrm{wt} \%)$ & $\mathrm{MnO}(\mathrm{wt} \%)$ & $\mathrm{ZnO}$ (wt\%) & $\mathrm{TiO}_{2}$ (wt\%) \\
\hline $\begin{array}{l}\text { Mn-Zn ferrite powder } \\
\text { (predetermined) }\end{array}$ & $70.55 \%$ & $20.89 \%$ & $8.56 \%$ & - \\
\hline $\begin{array}{l}\text { Mn-Zn ferrite powder } \\
\text { (experimental) }\end{array}$ & $66.2 \%$ & $26.2 \%$ & $7.5 \%$ & - \\
\hline $\begin{array}{l}\mathrm{Mn}-\mathrm{Zn} \text { ferrite } / \mathrm{TiO}_{2}\left(\mathrm{~N}_{2} 500^{\circ} \mathrm{C}\right) \\
\text { (experimental) }\end{array}$ & $28.4 \%$ & $8.5 \%$ & $2.9 \%$ & $60.1 \%$ \\
\hline
\end{tabular}




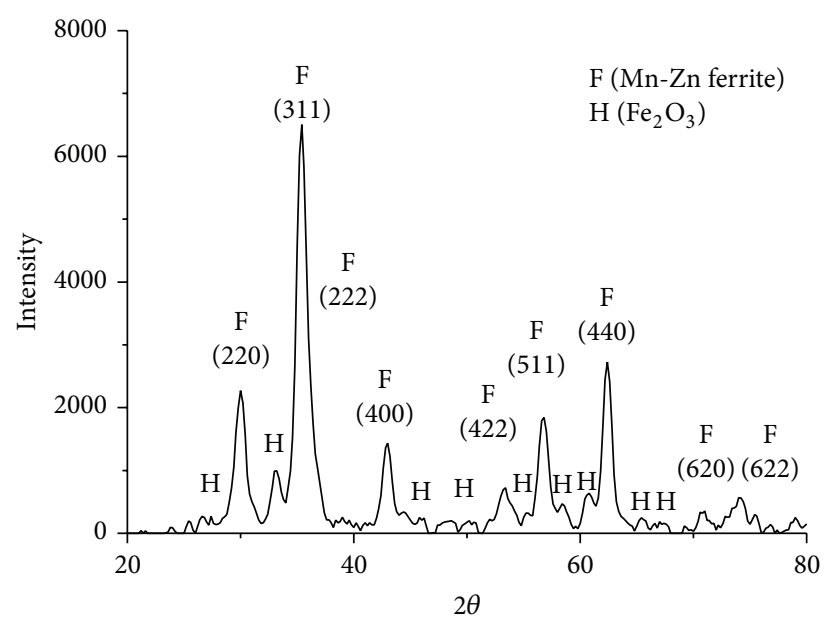

(a)

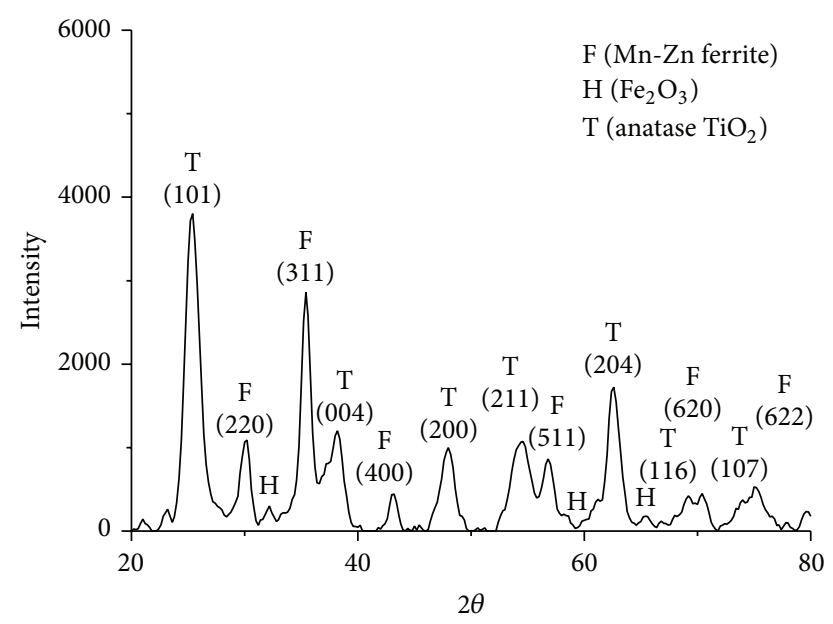

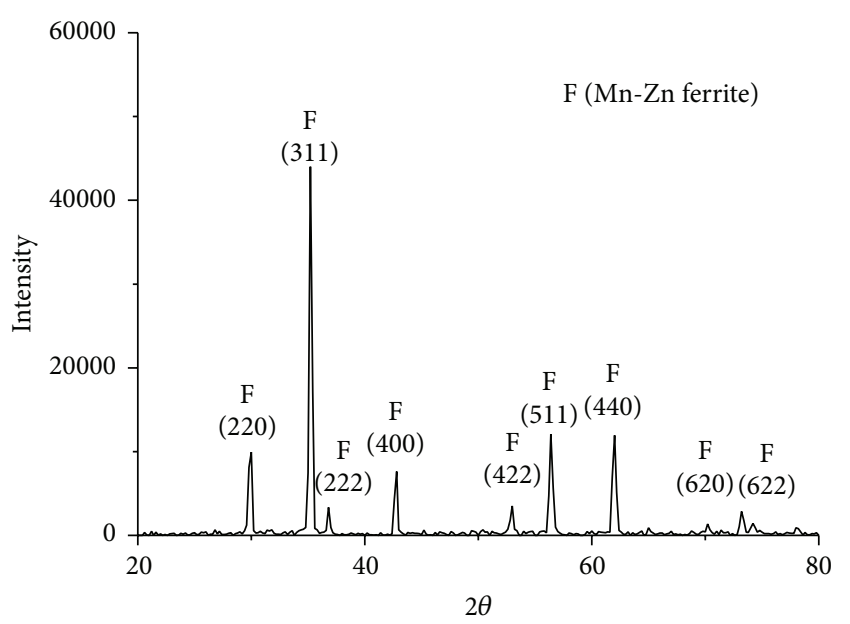

(b)

(c)

FIgURE 5: XRD pattern of $\mathrm{Mn}-\mathrm{Zn}$ ferrite powder (a), $\mathrm{Mn}-\mathrm{Zn}$ ferrite sintered at $1200^{\circ} \mathrm{C}\left(\mathrm{N}_{2}\right)(\mathrm{b})$, and $\mathrm{Mn}-\mathrm{Zn}$ ferrite/TiO ${ }_{2}\left(\mathrm{~N}_{2}, 500^{\circ} \mathrm{C}\right)(\mathrm{c})$.

and small $H_{c}$, the prepared magnetic materials are all softmagnetic materials. The magnetic property of the magnetic photocatalysts prepared from waste allows its recovery by the applied magnetic field.

3.3. Adsorption and Solar Photodegradation. The TOC and color ADMI removal percentage through the adsorption of $\mathrm{Mn}-\mathrm{Zn}$ ferrite $/ \mathrm{TiO}_{2}$ from FBL simulated dye wastewater, having initial dye COD concentrations of 100, 200, 300, or $400 \mathrm{mg} / \mathrm{L}$ and the weight ratio of ferrite powder: $\mathrm{TiO}_{2}$ maintained at $1: 1$, are shown in Figures 7 and 8. It is clear that adsorption by magnetic photocatalyst is much efficient for diluted solution but shows low efficiency for concentrated dye wastewater.

The photodegradation for simulated FBL dye wastewater with initial COD of 100, 200, 300, and $400 \mathrm{mg} / \mathrm{L}$ under solar irradiation by using self-produced magnetic photocatalysts from waste and also $\mathrm{TiO}_{2}$ prepared is shown in Figures 9 and $10 . \mathrm{TiO}_{2}$ was also produced by the same coprecipitation method. The degradation efficiency increased as the concentrations of pollutants decreased. For dilute pollution of FBL dye $(\mathrm{COD}=100 \mathrm{ppm})$, the TOC removal can reach $87.85 \%$ and color or ADMI removal can reach $96.17 \%$. The treatment efficiency by $\mathrm{Mn}-\mathrm{Zn}$ ferrite/ $/ \mathrm{TiO}_{2}$ from waste is very close to that of self-prepared $\mathrm{TiO}_{2}$ by treating dilute simulated dye wastewater. By using $\mathrm{TiO}_{2}$ only, TOC removal is $88 \%$ and color ADMI removal reached $96 \%$. Both dosages of $\mathrm{TiO}_{2}$ and magnetic photocatalysts were all $5 \mathrm{~g} / \mathrm{L}$.

3.4. Adsorption Isotherm. The Langmuir adsorption isotherm has the following equation [37]:

$$
Y=\frac{y_{m} K C_{e}}{1+K C_{e}} \quad \text { or } \quad \frac{C_{e}}{Y}=\frac{1}{K y_{m}}+\frac{C_{e}}{y_{m}},
$$

where $Y$ is the mass adsorbed per mass of adsorbent $(\mathrm{mg} / \mathrm{g})$, $y_{m}$ is the mass of the adsorbed solute required to completely saturate a unit mass of adsorbent or monolayer coverage $(\mathrm{mg} / \mathrm{g}), K$ is the adsorption constant $(\mathrm{L} / \mathrm{mg})$, and $C_{e}$ is the equilibrium TOC concentration of solute dye $(\mathrm{mg} / \mathrm{L})$. By plotting $C_{e} / Y$ against $C_{e}$ for different dye concentrations, straight line was obtained as shown in Figure 11. Adsorption 


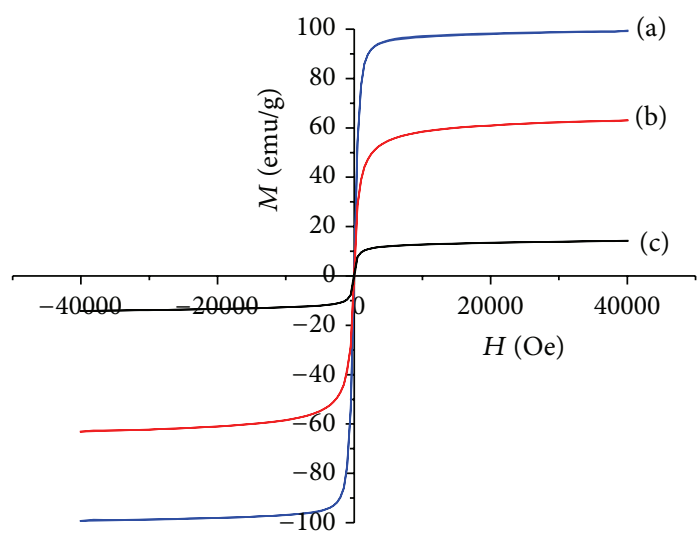

- (a) Mn-Zn ferrite $\left(\mathrm{N}_{2} 1200^{\circ} \mathrm{C}\right)$

- (b) Mn-Zn ferrite powder

- (c) $\mathrm{Mn}-\mathrm{Zn}$ ferrite/TiO ${ }_{2}\left(\mathrm{~N}_{2} 500^{\circ} \mathrm{C}\right)$

Figure 6: Hysteresis loop of Mn-Zn ferrite calcined at $1200^{\circ} \mathrm{C}$ (a), Mn-Zn ferrite powder without calcinations (b), and $\mathrm{Mn}-\mathrm{Zn}$ ferrite $/ \mathrm{TiO}_{2}$ calcined at $500^{\circ} \mathrm{C}$ (c).

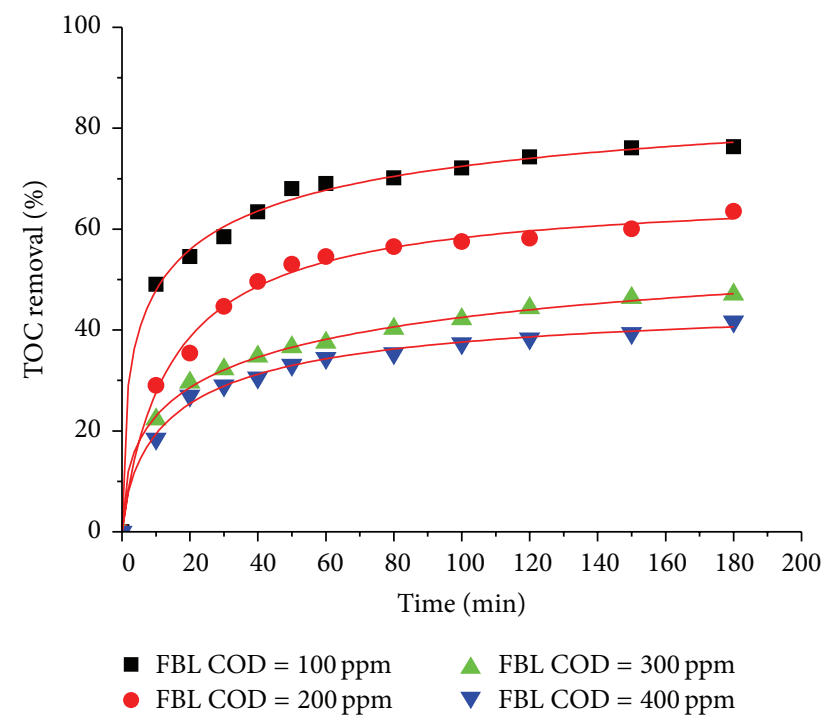

FIGURE 7: TOC removal \% versus time by adsorption of magnetic photocatalyst of $\mathrm{Mn}-\mathrm{Zn}$ ferrite $/ \mathrm{TiO}_{2}\left(\mathrm{~N}_{2}, 500^{\circ} \mathrm{C}\right)(\mathrm{FBL}, \mathrm{COD}=100-$ $400 \mathrm{ppm})$.

constants were determined by the $y$-intercepts of the lines and $1 / y_{m}$ were obtained from the slope. Their values were $11.53(\mathrm{mg} / \mathrm{g})$ for $y_{m}$ and $0.1014(\mathrm{~L} / \mathrm{mg})$ for $K$, respectively.

3.5. Langmuir-Hinshelwood Kinetic Model ( $\mathrm{L}-\mathrm{H}$ Model). The $\mathrm{L}-\mathrm{H}$ model can be expressed by the following equation [31]:

$$
r=-\frac{d C}{d t}=\frac{k_{r} K C}{1+K C}=\frac{k_{d} C}{1+K C}
$$

where $k_{r}$ is the photocatalytic reaction constant $[\mathrm{mg} /(\mathrm{L}-$ $\min )$ ], $k_{d}$ is the apparent degradation rate constant $\left(\min ^{-1}\right)$,

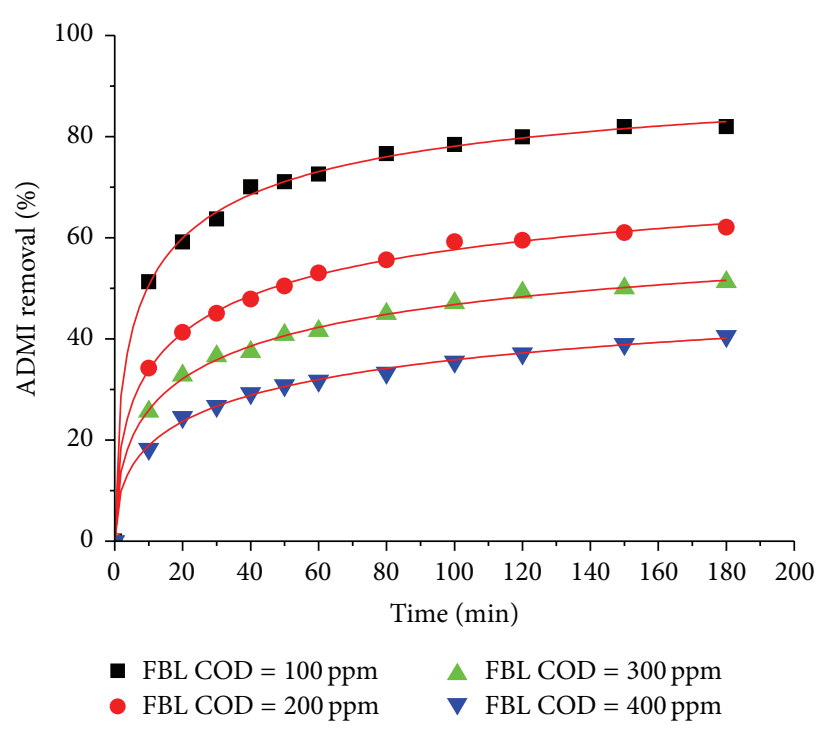

FIGURE 8: ADMI removal \% versus time by adsorption of magnetic photocatalyst of $\mathrm{Mn}-\mathrm{Zn}$ ferrite $/ \mathrm{TiO}_{2}\left(\mathrm{~N}_{2}, 500^{\circ} \mathrm{C}\right)(\mathrm{FBL}, \mathrm{COD}=100$ $400 \mathrm{ppm})$.

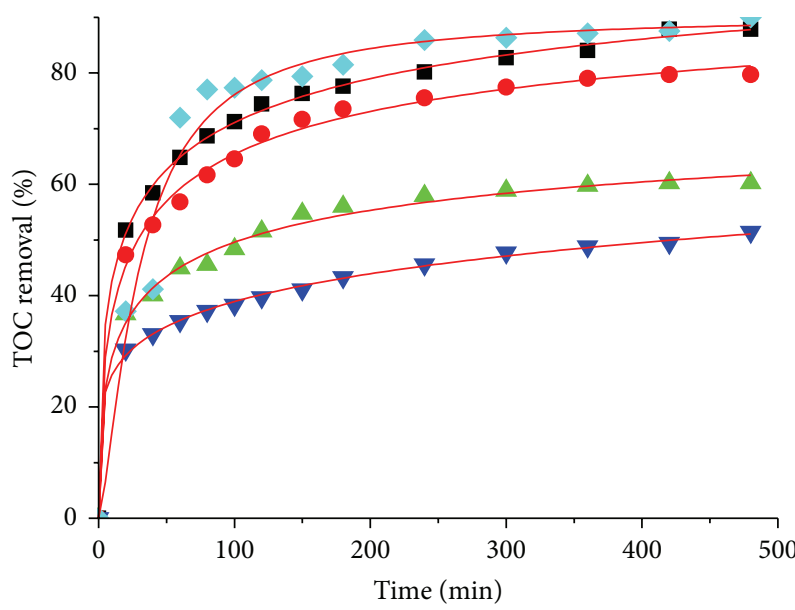

$$
\begin{aligned}
& \text { - } \mathrm{FBL} \mathrm{COD}=100 \mathrm{ppm} \quad \boldsymbol{F} \mathrm{FLCOD}=400 \mathrm{ppm} \\
& \text { - } \mathrm{FBL} C O D=200 \mathrm{ppm} \quad \mathrm{TiO}_{2} \mathrm{COD}=100 \mathrm{ppm} \\
& \triangle \mathrm{FBL} C O D=300 \mathrm{ppm}
\end{aligned}
$$

Figure 9: TOC removal \% versus time by using $\mathrm{Mn}-\mathrm{Zn}$ ferrite/ $/ \mathrm{TiO}_{2}$ $\left(\left.\mathrm{COD}\right|_{t=0}=100-400 \mathrm{ppm}\right)$ and $\mathrm{TiO}_{2}\left(\left.\mathrm{COD}\right|_{t=0}=100 \mathrm{ppm}\right)$ of $\mathrm{FBL}$ dye (dosage, $\left.5 \mathrm{~g} / \mathrm{L} ; I_{\mathrm{av} .}=0.8289 \mathrm{~mW} / \mathrm{cm}^{2}\right)$.

and $C$ is the dye concentration, TOC $(\mathrm{mg} / \mathrm{L})$. Combining zero-order and first-order reactions, the L-H model becomes

$$
-\ln \left(\frac{C}{C_{0}}\right)+K\left(C_{0}-C\right)=K_{r} K t .
$$

Let $C=0.87 C_{0}$ and $t=t_{0.87}$; the equation becomes

$$
t_{0.87}=\frac{0.1393}{k_{r} K}+\frac{0.13 C_{0}}{k_{r}} .
$$




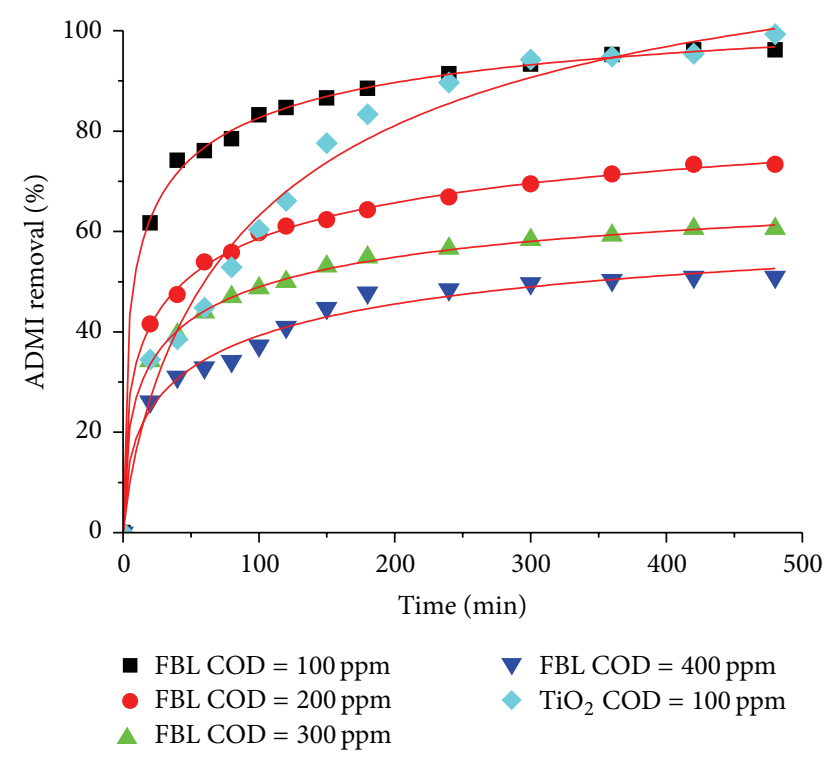

Figure 10: ADMI removal \% versus time by using $\mathrm{Mn}-\mathrm{Zn}$ ferrite $/ \mathrm{TiO}_{2}\left(\left.\mathrm{COD}\right|_{t=0}=100-400 \mathrm{ppm}\right)$ and $\mathrm{TiO}_{2}\left(\left.\mathrm{COD}\right|_{t=0}=\right.$ $100 \mathrm{ppm}$ ) of FBL dye (dosage, $\left.5 \mathrm{~g} / \mathrm{L} ; I_{\mathrm{av} .}=0.8289 \mathrm{~mW} / \mathrm{cm}^{2}\right)$.

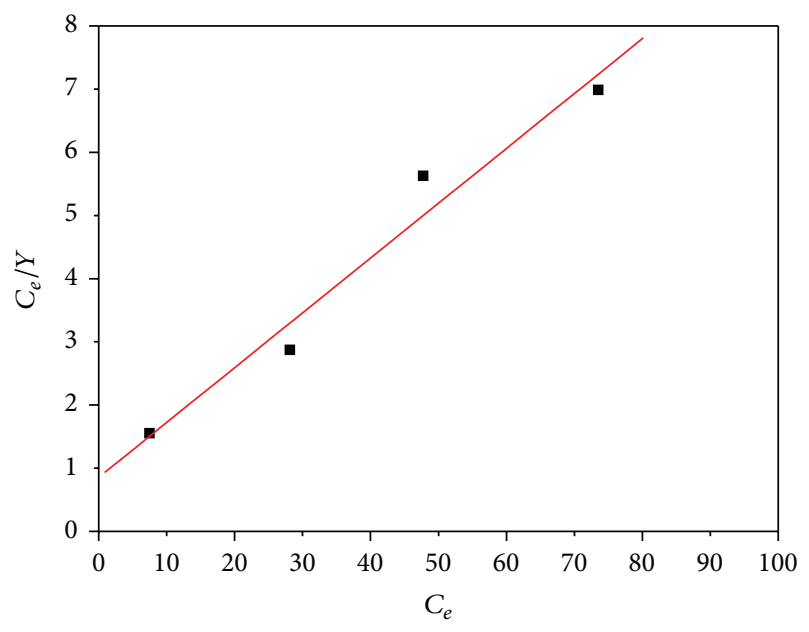

- $C_{e}$

$-Y=0.08677 X+0.85568, R^{2}=0.9658$

FIGURE 11: Langmuir adsorption isotherm for $\mathrm{Mn}-\mathrm{Zn}$ ferrite/ $/ \mathrm{TiO}_{2}$.

By plotting $t_{0.87}$ against $0.13 C_{0}$, the straight line was obtained and shown as in Figure 12. From the slope and intercept, the kinetic constants can then be calculated.

The constants obtained from adsorption isotherm and $\mathrm{L}-\mathrm{H}$ model were summarized in Table 2 . The adsorption constants for both isotherm and L-H model were very close. It means that adsorption by magnetic photocatalysts occurred first and then photodegradation followed. The result also shows that the L-H kinetic model fits well for the photodegradation of FBL simulated dye wastewater.

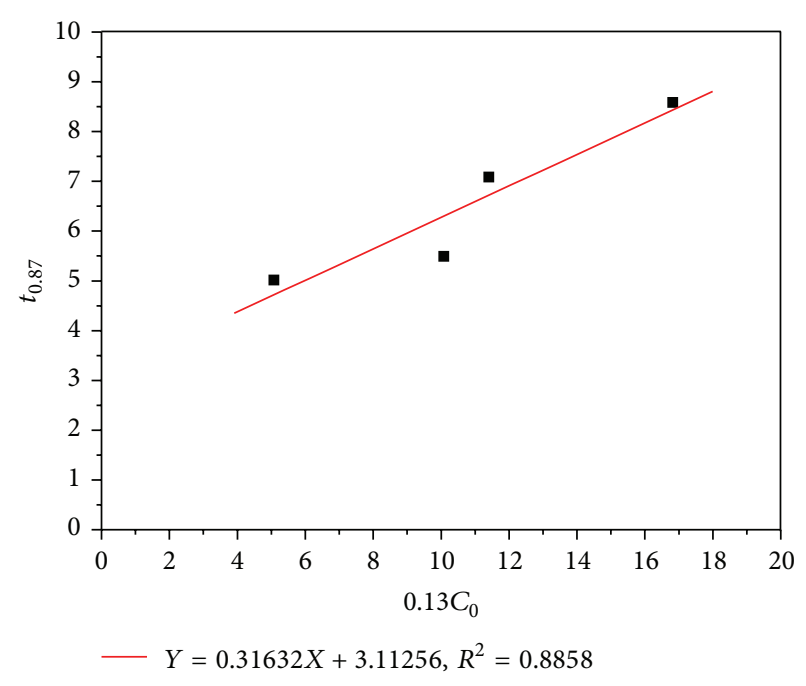

FIgURE 12: L-H kinetic model for the magnetic photocatalysts of $\mathrm{Mn}-\mathrm{Zn}$ ferrite/ $\mathrm{TiO}_{2}$.

TABLE 2: Adsorption constant for Langmuir isotherm and constants for L-H model.

\begin{tabular}{lcc}
\hline Constants & Langmuir & Langmuir-Hinshelwood \\
\hline$k_{r}(\mathrm{mg} / \mathrm{L} \min )$ & - & 3.1614 \\
$k_{d}\left(\mathrm{~min}^{-1}\right)$ & - & 0.3212 \\
$K(\mathrm{~L} / \mathrm{mg})$ & 0.1014 & 0.1016 \\
\hline
\end{tabular}

\section{Conclusions}

$\mathrm{Mn}-\mathrm{Zn}$ ferrite magnetic powder and the sintered $\mathrm{Mn}-\mathrm{Zn}$ ferrite were successfully prepared from spent dry batteries and steel picking sulfuric waste acid. The composition obtained is close to the designed value as molar ratio of $\mathrm{ZnO}: \mathrm{MnO}: \mathrm{Fe}_{2} \mathrm{O}_{3}=12.5: 35: 52.5$. The sintered Mn-Zn ferrite can be used directly in magnetic industry. The magnetic photocatalyst of $\mathrm{Mn}-\mathrm{Zn}$ ferrite/ $/ \mathrm{TiO}_{2}$ was also successfully produced by using magnetic powder, titanium sulfate, and urea as raw material and then followed by simple coprecipitation method. Comparing with JCPDS data, the XRD patterns of the photocatalyst contain $\mathrm{Mn}-\mathrm{Zn}$ ferrite, anatase $\mathrm{TiO}_{2}$, and a small amount of hematite. The magnetic photocatalyst falls into the category of soft-magnetic materials by SQUID study which can be recycled by the application of magnetic field. The treatment efficiency by magnetic photocatalyst of $\mathrm{Mn}$ $\mathrm{Zn}$ ferrite $/ \mathrm{TiO}_{2}$ for dilute simulated FBL dye wastewater can reach $87.85 \%$ of TOC removal and $96.17 \%$ of color removal and is very close to the efficiency of using $\mathrm{TiO}_{2}$ alone. The $\mathrm{Mn}-\mathrm{Zn}$ ferrite and magnetic photocatalyst produced from waste not only solve the pollution problems but also create the possibility of the benefits for the commercial applications. Both the Langmuir adsorption isotherm and L-H model fit well for the prepared magnetic photocatalyst and can be used successfully in AOP. 


\section{Conflict of Interests}

The authors declare that there is no conflict of interests regarding the publication of this paper.

\section{Acknowledgments}

This project was supported by the Ministry of Education, Taiwan, and Rui Da Hung Technology Materials Co., Ltd., Taiwan, under Contract no. 99G-39-03. The authors express sincere gratitude to the financial support for this research.

\section{References}

[1] S. H. Lin and M. L. Chen, "Combined ozonation and ion exchange treatments of textile wastewater effluents," Journal of Environmental Science and Health A, vol. 23, no. 7, pp. 10002010, 1997.

[2] I. Arslan, I. A. Balcioglu, T. Tuhkanen, and D. Bahnemann, " $\mathrm{H}_{2} \mathrm{O}_{2} / \mathrm{UV}-\mathrm{C}$ and $\mathrm{Fe}^{2+} / \mathrm{H}_{2} \mathrm{O}_{2} / \mathrm{UV}-\mathrm{C}$ versus $\mathrm{TiO}_{2} / \mathrm{UV}$-A treatment for reactive dye wastewater," Journal of Environmental Engineering, vol. 126, no. 10, pp. 903-911, 2000.

[3] D. Tomova, V. Iliev, S. Rakovsky, M. Anachkov, A. Eliyas, and G. L. Puma, "Photocatalytic oxidation of 2,4,6-trinitrotoluene in the presence of ozone under irradiation with UV and visible light," Journal of Photochemistry and Photobiology A: Chemistry, vol. 231, no. 1, pp. 1-8, 2012.

[4] Y. Nakamura, F. Kobayashi, M. Daidai, and A. Kurosumi, "Purification of seawater contaminated with undegradable aromatic ring compounds using ozonolysis followed by titanium dioxide treatment," Marine Pollution Bulletin, vol. 57, no. 1-5, pp. 53-58, 2008.

[5] F. Gozzi, A. Machulek Jr., V. S. Ferreira et al., "Investigation of chlorimuron-ethyl degradation by Fenton, photo-Fenton and ozonation processes," Chemical Engineering Journal, vol. 210, pp. 444-450, 2012.

[6] M. Karatas, Y. A. Argun, and M. E. Argun, "Decolorization of antraquinonic dye, Reactive Blue 114 from synthetic wastewater by Fenton process: kinetics and thermodynamics," Journal of Industrial and Engineering Chemistry, vol. 18, no. 3, pp. 10581062, 2012.

[7] S. Karthikeyan, A. Titus, A. Gnanamani, A. B. Mandal, and G. Sekaran, "Treatment of textile wastewater by homogeneous and heterogeneous Fenton oxidation processes," Desalination, vol. 281, no. 1, pp. 438-445, 2011.

[8] R. Liu, H. M. Chiu, C.-S. Shiau, R. Y.-L. Yeh, and Y.-T. Hung, "Degradation and sludge production of textile dyes by Fenton and photo-Fenton processes," Dyes and Pigments, vol. 73, no. 1, pp. 1-6, 2007.

[9] S. S. Abu Amr and H. A. Aziz, "New treatment of stabilized leachate by ozone/Fenton in the advanced oxidation process," Waste Management, vol. 32, no. 9, pp. 1693-1698, 2012.

[10] M. Čaplovičová, P. Billik, L'. Čaplovič et al., "On the true morphology of highly photoactive anatase $\mathrm{TiO}_{2}$ nanocrystals," Applied Catalysis B: Environmental, vol. 117-118, pp. 224-235, 2012.

[11] S. Bagwasi, B. Tian, J. Zhang, and M. Nasir, "Synthesis, characterization and application of bismuth and boron Co-doped $\mathrm{TiO}_{2}$ : a visible light active photocatalyst," Chemical Engineering Journal, vol. 217, pp. 108-118, 2013.
[12] M. Khraisheh, L. Wu, A. H. Al-Muhtaseb, A. B. Albadarin, and G. M. Walker, "Phenol degradation by powdered metal ion modified titanium dioxide photocatalysts," Chemical Engineering Journal, vol. 213, pp. 125-134, 2012.

[13] R. Liu, H. S. Wu, R. Yeh, C. Y. Lee, and Y. T. Hung, "Synthesis and bactericidal ability of $\mathrm{TiO}_{2}$ and $\mathrm{Ag}-\mathrm{TiO}_{2}$ prepared by coprecipitation method," International Journal of Photoenergy, vol. 2012, Article ID 640487, 7 pages, 2012.

[14] A. Charanpahari, S. S. Umare, S. P. Gokhale, V. Sudarsan, B. Sreedhar, and R. Sasikala, "Enhanced photocatalytic activity of multi-doped $\mathrm{TiO}_{2}$ for the degradation of methyl orange," Applied Catalysis A: General, vol. 443-444, pp. 96-102, 2012.

[15] Z. D. Meng, F. J. Zhang, L. Zhu et al., "Synthesis and characterization of $\mathrm{M}$-fullerene/ $/ \mathrm{TiO}_{2}$ photocatalysts designed for degradation azo dye," Materials Science and Engineering C, vol. 32, no. 8, pp. 2175-2182, 2012.

[16] S. Yamazaki, Y. Fujiwara, S. Yabuno, K. Adachi, and K. Honda, "Synthesis of porous platinum-ion-doped titanium dioxide and the photocatalytic degradation of 4-chlorophenol under visible light irradiation," Applied Catalysis B: Environmental, vol. 121122, pp. 148-153, 2012.

[17] B. Neppolian, A. Bruno, C. L. Bianchi, and M. Ashokkumar, "Graphene oxide based $\mathrm{Pt}-\mathrm{TiO}_{2}$ photocatalyst: ultrasound assisted synthesis, characterization and catalytic efficiency," Ultrasonics Sonochemistry, vol. 19, no. 1, pp. 9-15, 2012.

[18] S. R. Shirsath, D. V. Pinjari, P. R. Gogate, S. H. Sonawane, and A. B. Pandit, "Ultrasound assisted synthesis of doped $\mathrm{TiO}_{2}$ nanoparticles: characterization and comparison of effectiveness for photocatalytic oxidation of dyestuff effluent," Ultrasonics Sonochemistry, vol. 20, no. 1, pp. 277-286, 2013.

[19] S. Chakma and V. S. Moholkar, "Physical mechanism of sonofenton process," AIChE Journal, vol. 59, no. 11, pp. 4303-4313, 2013.

[20] S. Chakma and V. S. Moholkar, "Investigations in synergism of hybrid advanced oxidation processes with combinations of sonolysis + fenton process + UV for degradation of bisphenol A," Industrial and Engineering Chemistry Research, vol. 53, no. 16, pp. 6855-6865, 2014.

[21] P. M. Botta, P. G. Bercoff, E. F. Aglietti, H. R. Bertorello, and J. M. Porto López, "Two alternative synthesis routes for MnZn ferrites using mechanochemical treatments," Ceramics International, vol. 32, no. 8, pp. 857-863, 2006.

[22] A. Angermann, E. Hartmann, and J. Töpfer, "Mixed-metal carbonates as precursors for the synthesis of nanocrystalline MnZn ferrites," Journal of Magnetism and Magnetic Materials, vol. 322, no. 21, pp. 3455-3459, 2010.

[23] B. S. Randhawa, H. S. Dosanjh, and M. Kaur, "Preparation of spinel ferrites from citrate precursor route-a comparative study," Ceramics International, vol. 35, no. 3, pp. 1045-1049, 2009.

[24] R. Gimenes, M. R. Baldissera, M. R. A. Da Silva et al., "Structural and magnetic characterization of $\mathrm{Mn}_{x} \mathrm{Zn}_{1-x} \mathrm{Fe}_{2} \mathrm{O}_{4}(x=0.2$; $0.35 ; 0.65 ; 0.8 ; 1.0)$ ferrites obtained by the citrate precursor method," Ceramics International, vol. 38, no. 1, pp. 741-746, 2012.

[25] G. Xi, L. Yang, and M. Lu, "Study on preparation of nanocrystalline ferrites using spent alkaline $\mathrm{Zn}-\mathrm{Mn}$ batteries," Materials Letters, vol. 60, no. 29-30, pp. 3582-3585, 2006.

[26] L. Xiao, T. Zhou, and J. Meng, "Hydrothermal synthesis of MnZn ferrites from spent alkaline Zn-Mn batteries," Particuology, vol. 7, no. 6, pp. 491-495, 2009.

[27] J. Azadmanjiri, "Preparation of Mn-Zn ferrite nanoparticles from chemical sol-gel combustion method and the magnetic 
properties after sintering," Journal of Non-Crystalline Solids, vol. 353, no. 44-46, pp. 4170-4173, 2007.

[28] X. Cao, G. Liu, Y. Wang, J. Li, and R. Hong, "Preparation of octahedral shaped $\mathrm{Mn}_{0.8} \mathrm{Zn}_{0.2} \mathrm{Fe}_{2} \mathrm{O}_{4}$ ferrites via co-precipitation," Journal of Alloys and Compounds, vol. 497, no. 1-2, pp. L9-L12, 2010.

[29] P. P. Goswami, H. A. Choudhury, S. Chakma, and V. S. Moholkar, "Sonochemical synthesis of cobalt ferrite nanoparticles," International Journal of Chemical Engineering, vol. 2013, Article ID 934234, 6 pages, 2013.

[30] P. P. Goswami, H. A. Choudhury, S. Chakma, and V. S. Moholkar, "Sonochemical synthesis and characterization of manganese ferrite nanoparticles," Industrial \& Engineering Chemistry Research, vol. 52, no. 50, pp. 17848-17855, 2013.

[31] M. Ma, Y. Zhang, X. Li, D. Fu, H. Zhang, and N. Gu, "Synthesis and characterization of titania-coated Mn-Zn ferrite nanoparticles," Colloids and Surfaces A: Physicochemical and Engineering Aspects, vol. 224, no. 1-3, pp. 207-212, 2003.

[32] F. Chen and J. Zhao, "Preparation and photocatalytic properties of a novel kind of loaded photocatalyst of $\mathrm{TiO}_{2} / \mathrm{SiO}_{2} / \gamma-\mathrm{Fe}_{2} \mathrm{O}_{3}$," Catalysis Letters, vol. 58, no. 4, pp. 245-247, 1999.

[33] Y. Gao, B. Chen, H. Li, and Y. Ma, "Preparation and characterization of a magnetically separated photocatalyst and its catalytic properties," Materials Chemistry and Physics, vol. 80, no. 1, pp. 348-355, 2003.

[34] Y.-P. Fu, W.-K. Chang, H.-C. Wang, C.-W. Liu, and C.-H. Lin, "Synthesis and characterization of anatase $\mathrm{TiO}_{2}$ nanolayer coating on $\mathrm{Ni}-\mathrm{Cu}-\mathrm{Zn}$ ferrite powders for magnetic photocatalyst," Journal of Materials Research, vol. 25, no. 1, pp. 134-140, 2010.

[35] APHA, Standard Methods for the Examination of Water and Wastewater, American Public Health Association/American Water Works Association/Water Environment Federation, Washington, DC, USA, 21th edition, 2003.

[36] C. F. Wu, Preparation characterization and application of $\mathrm{Mn}-\mathrm{Zn}$ ferrite powders and magnetic titanium dioxide from used dry batteries and spent steel pickling liquids [M.S. thesis], Department of Chemical and Materials Engineering, Minghsin University of Science and Technology, Hsinchu, Taiwan, 2012.

[37] R. Y. L. Yeh and A. Thomas, "Color removal from dye wastewaters by adsorption using powdered activated carbon: mass transfer studies," Journal of Chemical Technology and Biotechnology, vol. 63, no. 1, pp. 48-54, 1995. 

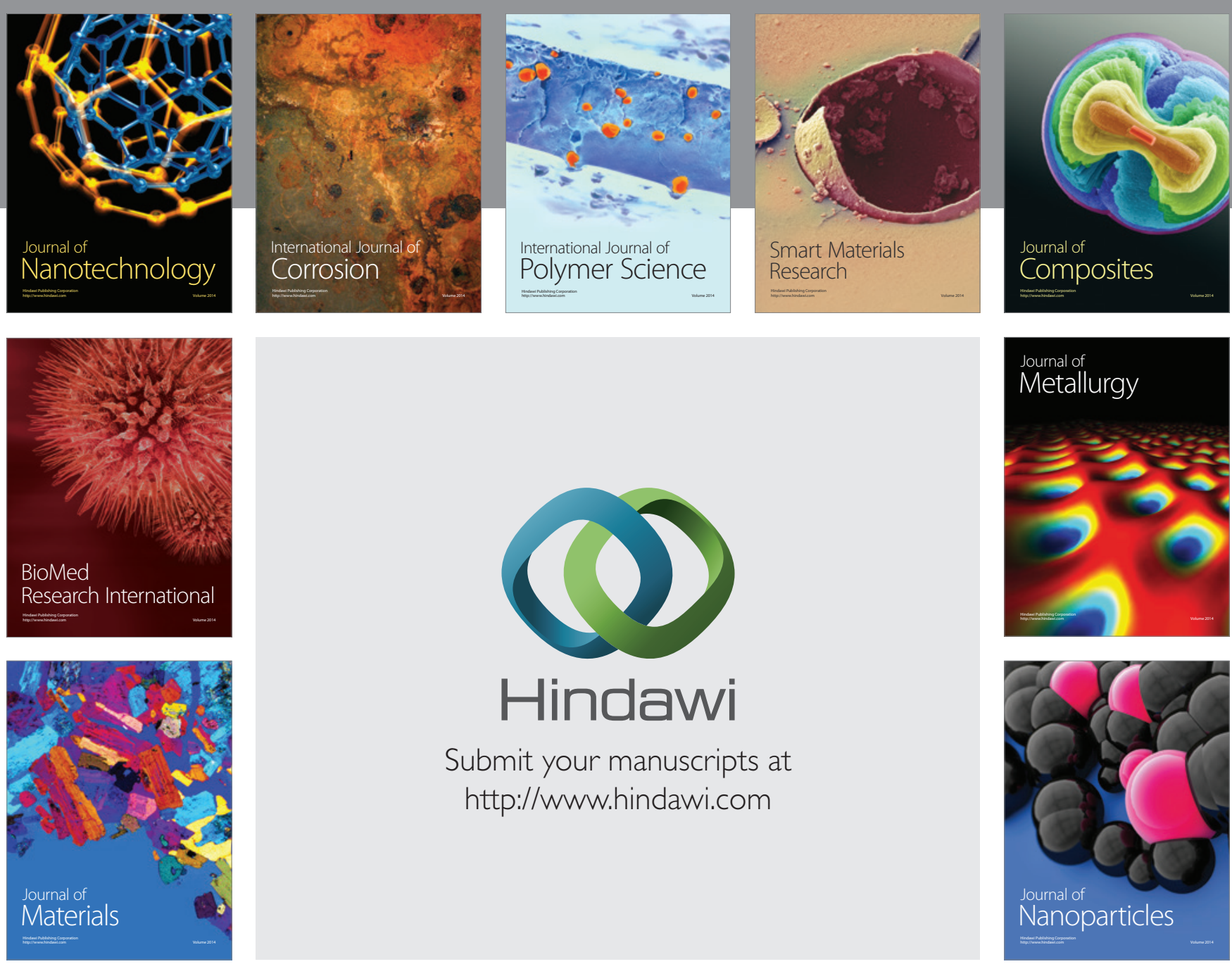

Submit your manuscripts at http://www.hindawi.com
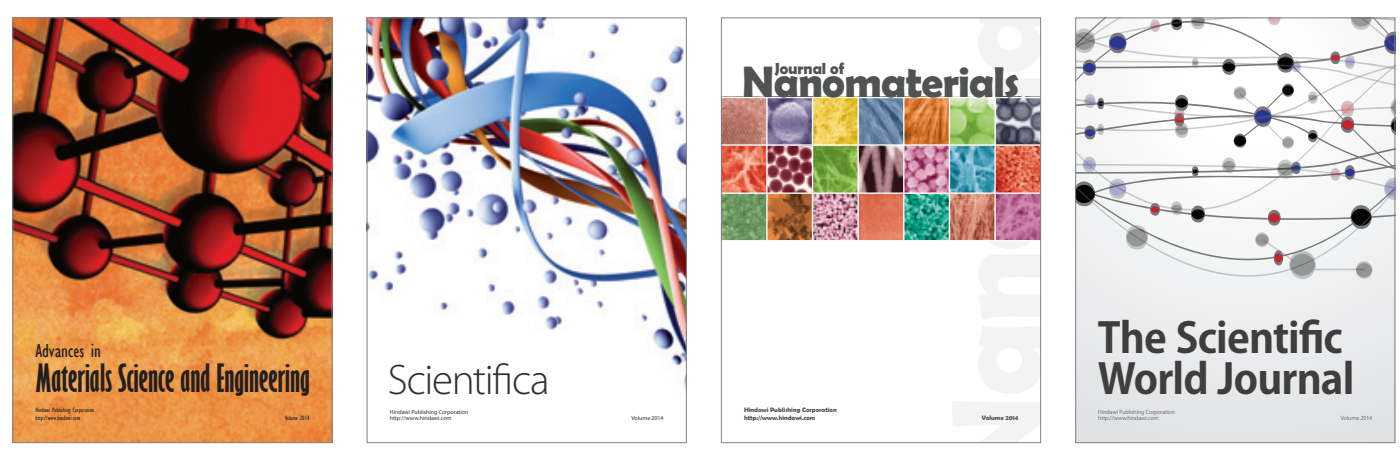

\section{The Scientific World Journal}
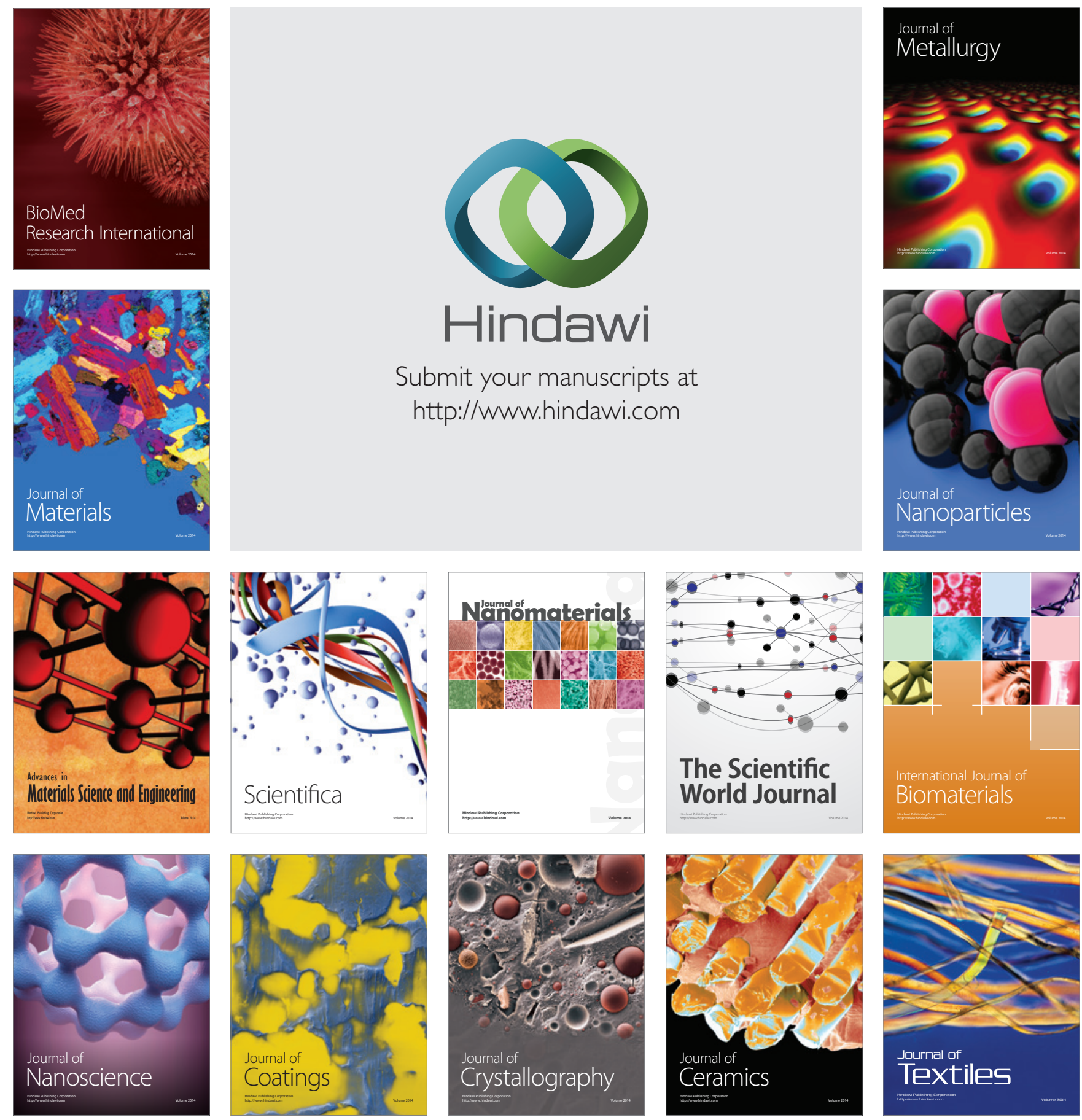